\title{
ECONOMIC GROWTH, ENERGY CONSUMPTION ENVIRONMENTAL POLLUTION IN NIGERIA: EVIDENCE FROM ARDL APPROACH
}

\author{
Kabiru Saidu Musa ${ }^{1+}$ \\ Rabiu Maijama'a ${ }^{2}$
}

\author{
${ }^{\prime}$ Department of Economics, Faculty of Social and Management Sciences, \\ Bauchi State University Gadau, Yuli Campus, Bauchi-Nigeria. \\ Email:kabirusaidumusa@gmail.com Tel.+2348030915903 \\ ${ }^{2}$ Nigerian National Petroleum Corporation, NNPC Towers, Central \\ Business District, Garki, Abuja-Nigeria. \\ Email:Rabiumaijamaa19@.gmail.com Tel: +2348033896237
}

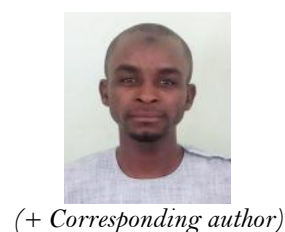

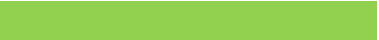

Article History

Received: 8 July 2020 Revised: 16 August 2020 Accepted: 1 September 2020 Published: 14 September 2020

\section{Keywords}

Economic growth

Energy consumption

Environmental pollution

ARDL approach

ADF

$\mathrm{PP}$ unit root tests

Johansen

Juselius cointegration

Nigeria.

JEL Classification:

F43, F64, O13, Q53, O55.

\begin{abstract}
The objective of this paper is to investigate the influence of economic growth and energy consumption on environmental pollution in Nigeria for over 1981-2014 periods and utilized Augmented Dickey Fuller (ADF) and Philip Perron (PP) unit root tests together with Autoregressive Distributed Lag (ARDL) Model in the process of achieving the desire objective. The outcome revealed that all the variables were stationary at first difference and cointegrated whereas the long-run outcome revealed that economic growth and energy consumption have significant positive effects on environmental pollution and this implies that increasing economic growth and energy consumption are responsible for the increasing level of environmental pollution while crude oil price has negative and significant influence on environmental pollution which implies that crude oil price reduces environmental pollution in the long-run. All the short-run outcomes corroborate their long-run counterparts. Nigeria government should emphasis more on the consumption of renewable energy in order to lessen the damaging impacts of economic activities and fossil fuels energy consumption on the quality of the country's environment.
\end{abstract}

Contribution/ Originality: The study contributes to the existing literatures by providing evidence that economic growth and energy consumption are responsible for the environmental pollution. The study is among the very few studies that include crude oil price in investigating the impacts of economic growth and energy consumption on environmental pollution in Nigeria.

\section{INTRODUCTION}

The nation's energy sector is a multi-purpose sector that does not work in line with the real economic part and there are uncountable events in the energy sector that have the capacity to influence the remaining parts of the nation and vice versa. Each and every time an economic action takes place in a nation, the energy sector is motivated to have some of the greatest powerful outcomes which can influence the area either positively or negatively (Mahmood, Furqan, \& Bagais, 2019). It is acknowledged by Maji (2015) that there is an existing relationship between trade openness and economic growth. Using Nigeria as a case study and the data for the period spanning 1981 to 2011 was utilized to obtain the outcomes. Moreover, environmental pollution was found to exist in the context of the country and the outcome revealed that trade openness and economic growth have 
significant negative impact on environmental pollution and this suggest that economic growth and trade openness improves the quality of the environment. The case of Pakistan, Ahmed, Shahbaz, Qasim, and Long (2015) scrutinize the influence of some macroeconomic series on deforestation and confirmed the presence of Environmental Kuznet Curve (EKC) as demonstrated by the falling influence of economic growth on deforestation for the quality of the environment. Using the same case study, Hassan, Tahir, Wajid, Mahmood, and Farooq (2017) carried out an investigation for the purpose of revealing the existence of long-run equilibrium and causal relationships among energy, economic growth and energy management policies and the investigation was possible with the help of time series data for over 1977-2013 periods. The outcomes revealed that economic growth can be affected by the nation's energy management policies whereas gas consumption have positive and significant outcome on the nation's level of income. The study has provided strong policy suggestion for the nation's economy. Again, by considering the time series data for the period of 1991 to 2014 covering East Asian nations, Mahmood et al. (2019) shows that trade openness, foreign direct investment and financial market development have strong influence on per capita $\mathrm{CO}_{2}$ emissions and the spillover influences of trade openness, foreign direct investment and financial market development have been confirmed and specified that nation's foreign trade events influence the country's environment and the bordering countries. The existence of Environmental Kuznets Curve (EKC) was confirmed in the region with financial market development and trading activities appeared to influence the nation environmental profile which bring about degradation in its environment. The outcomes advocate solid implication for Asian nations and recommend that the Asian nations should also consider the environmental and economic aspect of other neighboring nations into consideration apart from their own economies.

In their study, Shahbaz, Solarin, Mahmood, and Arouri (2013) revealed that financial development and trading activities have negative influence on environmental pollution but economic growth and the level of energy consumption are accountable for degrading the environmental quality in Malaysia. Even though the analysis makes some sense but has leaves some spaces for additional investigation to be carried out and most importantly that level of income causes rises in $\mathrm{CO}_{2}$ emissions while trading activities and financial development do not. Saudi Arabia as their case study, Alkhateeb, Alkahtani, and Mahmood (2018) discovered that financial market has contributed a lot in $\mathrm{CO}_{2}$ emissions. As a practical suggestion to this examination, economic growth is associated with higher energy consumption, which will go alone way in bringing about higher $\mathrm{CO}_{2}$ emissions. additional, this connection indicate that increase in country's economic activities is correlated with worsening the environment because it brings about increase in the level of energy consumption. In this situation, the knowledge of Environmental Kuznet Curve should be put into consideration as $\mathrm{CO}_{2}$ emissions is caused by economic growth but gradually when the nation become industrially established, the level of $\mathrm{CO}_{2}$ emissions begins to decrease (Mahmood et al., 2019). In the economy Nigeria, the presence of Environmental Kuznet Curve was confirmed in the investigation but additional investigation became mandatory to separate whether $\mathrm{CO}_{2}$ emissions influenced by energy consumption and the level of income, which is something this present research has the intentions of examining. Talking about the Nigeria and the giant economy in sub-Saharan Africa, the background of crude oil prices and added associated measures cannot be disregarded because including crude oil prices in the examination can offer additional background to a certain level while the profile of the nation's environment becomes formed. Musa, Maijama'a, Shaibu, and Muhammad (2019) studied the impacts of crude oil price and exchange rate on economic growth using time series data spanning 1982-2018 and applied ARDL approach to discover the cointegration, short-run and long-run relationships among the variables. The outcome indicate that crude oil price and exchange rate have significant positive effects on the economic growth for the period under study and the researchers conclude that Nigerian government should expand its means of revenue generation through other means in order to reduce over reliance on single export commodity.

Our study can offer some assistance to balance other researches carried out on alike theme in Nigeria. The result produced from the investigation will useful in formulating sound policy for the nation's energy sector with 
the aim of maintaining equilibrium between economic and energy sectors and to make sure that nothing blunders through the cracks which come back and gives a negative hit to Nigerian economy.

\section{LITERATURE REVIEW}

There are dozens of literatures on the relationship between macroeconomic series and how they influenced $\mathrm{CO}_{2}$ emissions. Our review of related literatures concerning the influence of economic growth and energy consumption on environmental pollution is divided into two strands. The first strands will concentrate on the relationship between economic growth and environmental pollution followed by the relationship between energy consumption and environmental pollution.

The first strands of the literatures started with the snap shoot from the pioneer work of Kraft and Kraft (1978) explored the association between economic growth and energy consumption over 1947-1974 periods in United States and immediate after this discovery, many empirical investigations followed with various approaches of investigation among them are Acaravci and Ozturk (2010) studied the causal association between economic growth, $\mathrm{CO}_{2}$ emissions and energy consumption for the period of 1960 to 2005 using 19 European member nations as the case study. By means of applied ARDL bound test for cointegration and granger causality based on ECM, the study revealed the existence of long run equilibrium relationship together with long run unidirectional causality running among the variables in Germany, Denmark, Greece, Iceland, Portugal, Italy and Switzerland. Arouri, Youssef, M'henni, and Rault (2012) examine the association between $\mathrm{CO}_{2}$ emissions, economic growth and energy consumption for the sample period of 1981 to 2005 covering 12 Middle East and North African Nations (MENA). They applied bootstrap panel unit root tests and cointegration methods and the findings indicate that there is an existence of positive and significant association between energy consumption and $\mathrm{CO}_{2}$ emissions with economic growth showing quadratic association with $\mathrm{CO}_{2}$ emissions for the entire regions. In the process of investigating the existence of causal relationship between energy consumption and economic growth for 1990-2009 periods in selected European Union member countries through the use of ARDL approach, Alper and Oguz (2016) shows that there exists significant positive influence of renewable energy consumption on economic growth and the influence was not the same for all the member countries as the significant positive influence was only found in, Poland, Slovenia, Bulgaria and Estonia with no evidence of causal relationship in Hungary, Cyprus, Poland, Slovenia and Estonia. By investigating the effects of economic growth, foreign direct investment and financial development on $\mathrm{CO}_{2}$ emissions in Kuwait, Salahuddin, Alam, Ozturk, and Sohag (2017) make used of ARDL approach and VECM to analyze the data for 1980-2013 periods and the outcomes indicate that economic growth, FDI and electricity consumption encourage the emissions of $\mathrm{CO} 2$ together with economic growth, FDI and electricity consumption granger causing $\mathrm{CO} 2$ emissions from VECM in Kuwait. Using South Africa as a case study and covered a sample period of 1971-2013, Khobai and Le Roux (2017) scrutinized the association between economic growth, energy consumption, urbanization and trade openness with the help of granger causality test through VECM and the results shows that there is an equilibrium relationship between the variables and that bidirectional causality exists running from energy consumption to economic growth and conclude that South Africa government should endorse energy strategy for better economic growth. The outcome of investigating the impacts of foreign direct investment on $\mathrm{CO}_{2}$ emissions through combination of cointegration test based on method of structural break bootstrap and ordinary least squares estimator in the case of Turkey, Koçak and Sarkgüneşi (2018) discovered that improving economic growth reduces the country's level of $\mathrm{CO} 2$ emissions within the investigating periods of 1974-2013. Ahmad et al. (2018) after applying ARDL approach and granger causality test for the possible existence of causal relationship among economic growth, energy consumption and $\mathrm{CO}_{2}$ emissions revealed that there is a long-run equilibrium relationship between the variables and that unidirectional causality exists running from economic growth to $\mathrm{CO}_{2}$ emissions and this outcomes led to a conclusion that energy use and economic growth encouraged the emissions of $\mathrm{CO}_{2}$ in China for the period of 1971-2013. Sarkodie and Strezov (2019) after covering South Africa, 
Indonesia, Iran, China and India for being the leading emitters of $\mathrm{CO}_{2}$ among the developing countries for the period spanning 1982-2016, the outcome of the investigation indicates that significant positive impacts of energy consumption on $\mathrm{CO}_{2}$ emissions and that net foreign direct investment inflows can lead to changes in economic growth, labour upgrade and transfer of technology with economic management among the developing countries. after applying ADRL approach to analyze the time series data for the period of 1991-2015, Kouton and Amonle (2019) explore the influence of consuming renewable energy on economic growth in Cote d'Ivoire and the outcome revealed that the influence is mixed in the short-run while the it is insignificant in the long-run and that brings to a conclusion that energy consumption transition is on the process in the country. In discovering the relationship between environmental pollution, energy consumption, foreign direct investment and economic growth within the context of selected 6 sub-Saharan Africa covering the period of 1980 to 2014, Ssali, Du, Mensah, and Hongo (2019) applied panel cointegration and ARDL in view of the PMG revealed that bidirectional causality exist running from energy use to $\mathrm{CO}_{2}$ emissions in the short-run and long-run unidirectional causality also exists running from energy use to $\mathrm{CO}_{2}$ emissions and from $\mathrm{CO}_{2}$ to foreign direct investment all in the study periods in selected sub-Saharan Africa.

Following the first strands of literature review, the second strands focuses on the relationship between energy consumption and environmental pollution as documented in the works of Bloch, Rafiq, and Salim (2012) studied the connection between coal consumption and emission of pollution using data for two sample periods of 1965 to 2008 and 1977 to 2008 in the case of Chinese economy for the demand and the supply sides in the short-run and long-run periods. The outcome indicates that there is unidirectional causality running form coal consumption to outcome in the short-run and long-run under both supply and demand sides whereas bidirectional causality also exists running from income to coal consumption in the two periods. Using ARDL approach to analyze the data for the period covering 1979-2014 on the variables of interest in Iran, Khoshnevis Yazdi and Shakouri (2017) inspect the connection between consuming renewable energy and economic growth and the outcome from the inspection revealed that economic growth is influenced by the consumption of renewable energy negatively in the long-run and the short-run periods. In the case of Pakistan economy, Mirza and Kanwal (2017) investigates the presence of causal relationship between energy consumption, economic growth and environmental pollution using the ARDL approach and granger causality based on VECM approach. The outcome of the investigation indicates that there exists cointegration relationship among these variables and that bidirectional causality exists among energy consumption, economic growth and environmental pollution and based on this finding, they conclude that government of Pakistan should increase the consumption of renewable energy consumption. But in the case of Algerian economy, Amri (2017) studied the influence of nonrenewable energy consumption on economic growth and showed that long run causality exists in a unidirectional way running from renewable energy consumption to economic growth alongside short run unidirectional causality running from nonrenewable to renewable energy consumption. While in the provinces of China, Ahmad et al. (2018) utilized ARDL approach to study the influence of energy consumption, economic growth and total population on $\mathrm{CO}_{2}$ emissions over 1971-2013 periods. Their outcome recognizes a connection between economic growth and $\mathrm{CO}_{2}$ emissions which confirms the existence of cointegration among the variables. Granger causality test result shows the presence of unidirectional causality among economic growth and $\mathrm{CO}_{2}$ emissions and lastly, outcome shows that energy consumption and economic growth are responsible for the increasing level of $\mathrm{CO}_{2}$ emissions in the country. In another development, Isik, Dogru, and Turk (2018) investigated the influence of energy consumption, urbanization and economic growth on environmental pollution in the case of Chinese economy using heterogeneous panel technique of data analysis such as dynamic ordinary least squares, fully modified least squares and panel Granger causality test. The outcome indicates that energy consumption, urbanization and economic growth are accountable for the environmental pollution in the entire provincial panel. In the case of G-7 member nations and applied method of historical decomposition, Balcilar, Ozdemir, Ozdemi, and Shahbaz (2018) investigates the existing relationship between 
energy consumption, economic growth and $\mathrm{CO}_{2}$ emissions and the outcome revealed that it is required that nations such as Italy, USA, Japan and Canada need to surrender those economic activities in order to lessen $\mathrm{CO}_{2}$ emissions by prohibiting the consumption of energy from non-renewable source while for Germany, US, Canada, Japan and UK the result indicate that environmental kuznet curve does not hold as the environmental quality is not affected by economic growth in UK and Germany. Okwanya and Abah (2018) examined the influence that energy consumption has on reducing the level of poverty in 12 selected African nations for the sample period covering 1981-2014. Fully modified ordinary least squares and granger causality test were utilized and the outcome indicates that there is significant negative influence of energy consumption on the level of poverty and that unidirectional causality exists running from energy consumption to poverty and this implies that growing energy consumption brings about reduction in poverty. By exploring the connection between energy demand and its determinants particular global crude oil price, population, urbanization and economic growth for period spanning 2000-2016 using the case of the Association of Southeast Asian Nations (ASEAN), Hassan (2018) shows that at access to energy, economic growth and urbanization have significant influence on the demand of energy at the aggregated level whereas the outcome is not the same at the dis-aggregated level. In the case of Morocco, Fatiha and Karim (2019) scrutinized the determining factors for energy demands for the 1990-2016 periods and utilized Error Correction (ECM) model to provide empirical results for the analysis. The outcomes indicate that economic growth, foreign direct investment and access to electricity are the real determining factors for energy demands for the period under study in the country.

Therefore, it can be seen already that from the above reviewed literature the study on a relationship between economic growth and energy consumption on environmental pollution is lacking in the case of Nigeria. However, in line with this gap, the current study will contribute to the existing literatures by studying the impact of economic growth and energy consumption on environmental pollution in the case of Nigeria for the periods covering 19812014 and apply autoregressive distributed lag model.

\section{RESEARCH METHODOLOGY}

The main objective of the study is to investigate the contributing factors to $\mathrm{CO}_{2}$ emissions which are economic growth (EG) and energy consumption (EC). With the considerable growing level of income and in the course of economic growth, a meaningful quantity of energy is needed in fueling the economic activities. Precisely, the demand for energy is high in the production sector of the economy for running the machines. Again, increase in economic growth is connected with increase in transportation activities and infrastructure Since both of them need energy to function and air pollution would be their outcome. Moreover, the increasing energy consumption by domestic utensils and the individual's automobiles are connected with the country's growing economic growth. The growing consumption of energy might be accountable for the rising level of $\mathrm{CO}_{2}$ emissions as the most important part of the energy consumption comes from fossil fuel sources in the country and to capture the influence of such determining factors, we assumed the following model in Equation 1.

$$
C \mathrm{O}_{t}=f\left(E C_{t}, E G_{t}, O P_{t}\right)
$$

To decrease skewness in the time series data, the natural logarithmic linear specification offers healthier outcomes when related with functional form linear Equation and as such, following researchers such as Epule, Peng, and Lepage (2014); Ahmed et al. (2015); Maji (2015); Musa et al. (2019), we adapt and developed a logarithmic linear econometric model that consist of drift coefficient and the disturbance term, where the disturbance term is anticipated to be normally distributed with zero mean and constant variance. Therefore, the econometric association between our series is given in Equation 2:

$$
\ln C O_{2 t}=\beta_{0}+\beta_{1} \ln E G_{t}+\beta_{2} \ln E C_{t}+\beta_{3} \ln O P_{t}+\varepsilon_{t}
$$


where environmental pollution is measured as $\mathrm{CO}_{2}$ emissions which is denoted as $\mathrm{CO}_{2 \mathrm{t}}$. the economic growth comprises of the economic activities that are accountable for the growing amount of energy consumption and resulting pollution is represented as $\mathrm{EG}_{\mathrm{t}}$. The energy consumption from fossil fuels is represented as $\mathrm{EC}_{\mathrm{t}}$. Brent crude oil price was capture as $\mathrm{OP}_{\mathrm{t}}$. The data for the periods of 1981 to 2014 on all the variables were extracted from WDI (2020) and OPEC (2020). But before carrying out the regression estimation, we will first of all test for the presence of unit root in Equation 1 and then continue further to determine the order of integration of the series and to achieve this purpose, we engaged (Dickey \& Fuller, 1981) and Phillips and Perron (1988) Unit root tests and after knowing the series order of integrations in Equation 1, we followed it with the long-run equilibrium relationship using the bound test of Pesaran, Shin, and Smith (2001).

$$
\begin{aligned}
\Delta \ln C O_{2 t}=\phi_{0} & +\sum_{k=1}^{p} \chi_{1 k} \Delta \ln C O_{2 t-k}+\sum_{k=0}^{q} \chi_{2 k} \Delta \ln E C_{t-k}+ \\
& \sum_{k=0}^{r} \chi_{3 k} \Delta \ln E G_{t-k}+\sum_{k=0}^{s} \chi_{4 k} \Delta \ln O P_{t-k}+ \\
& \beta_{1 k} \ln C O_{2 t-k}+\beta_{2 k} \ln E C_{t-k}+\beta_{3 k} \ln E G_{t-k}+ \\
& \beta_{4 k} \ln O P_{t-k}+\mu_{1 t}
\end{aligned}
$$

where $\ln$ is natural $\log$-sign, $\Delta$ represent short-run sign, $\chi_{1} \ldots . \chi_{4}$ represent the long-run coefficients, $\beta_{1} \ldots . . \beta_{4}$ denotes the short-run parameters, $\sum$ stand for the summation and $\mu$ is the error term. The existence of cointegration relationship is tested using the null hypothesis $\beta_{1}=\beta_{2}=\beta_{3}=\beta_{4}=0$ and rejection of the null hypothesis confirmed the existence of cointegration relationship in Equation 2 and the null hypothesis is tested following the selection of optimal lag length p, q, r, s in Equation 2. Additionally, all the reliability tests were carried out on Equation 3 in order to ensure the achievements of uniformity and reliability of the calculated Equation. To apprehend the long-run elasticity coefficients in determining the influence of $\mathrm{EC}_{\mathrm{t}}, \mathrm{EG}_{\mathrm{t}}$ and $\mathrm{OP}_{\mathrm{t}}$ on the $\mathrm{CO}_{2 \mathrm{t}}$ in Equation 3, we normalized $\beta_{2}$ and $\beta_{3}$ by $\beta_{1}$ and after this is done, the short-run impacts of $\mathrm{EC}_{\mathrm{t}}, \mathrm{EG}_{\mathrm{t}}$ and $\mathrm{OP}_{\mathrm{t}}$ on $\mathrm{CO}_{2 \mathrm{t}}$ may be calculated by means of Equation 4 .

$$
\begin{gathered}
\Delta \ln C O_{2 t}=\phi_{1}+\sum_{k=1}^{p} \chi_{1 k} \Delta \ln C O_{2 t-k}+\sum_{k=0}^{q} \chi_{2 k} \Delta \ln E C_{t-k}+ \\
\sum_{k=0}^{r} \chi_{3 k} \Delta \ln E G_{t-k}+\sum_{k=0}^{s} \chi_{4 k} \Delta \ln O P_{t-k}+ \\
\vartheta E C T_{t-1}+\mu_{2 t}
\end{gathered}
$$

The existence of short-run relationship in Equation 4 depends on $\vartheta$ being negative and significant and it also depicts the speed of adjustment back to equilibrium from disequilibrium position. After that, the calculated parameters of differenced series are considered as short-run elasticity values. 


\section{DATA ANALYSES AND DISCUSSIONS}

The data on all the variables was analyzed with help of Eviews 10. Following the estimation procedures mentioned earlier, the series were tested for the possible existence of unit root and the results is reported in Table 3. But before the discussion of the unit root tests results, let's look at some preliminary tests such as the graphical illustration of our variables, the descriptive analysis that gives some insight on our variables and the correlation analysis. The graphical presentation of our variables is offered in Figure 1.
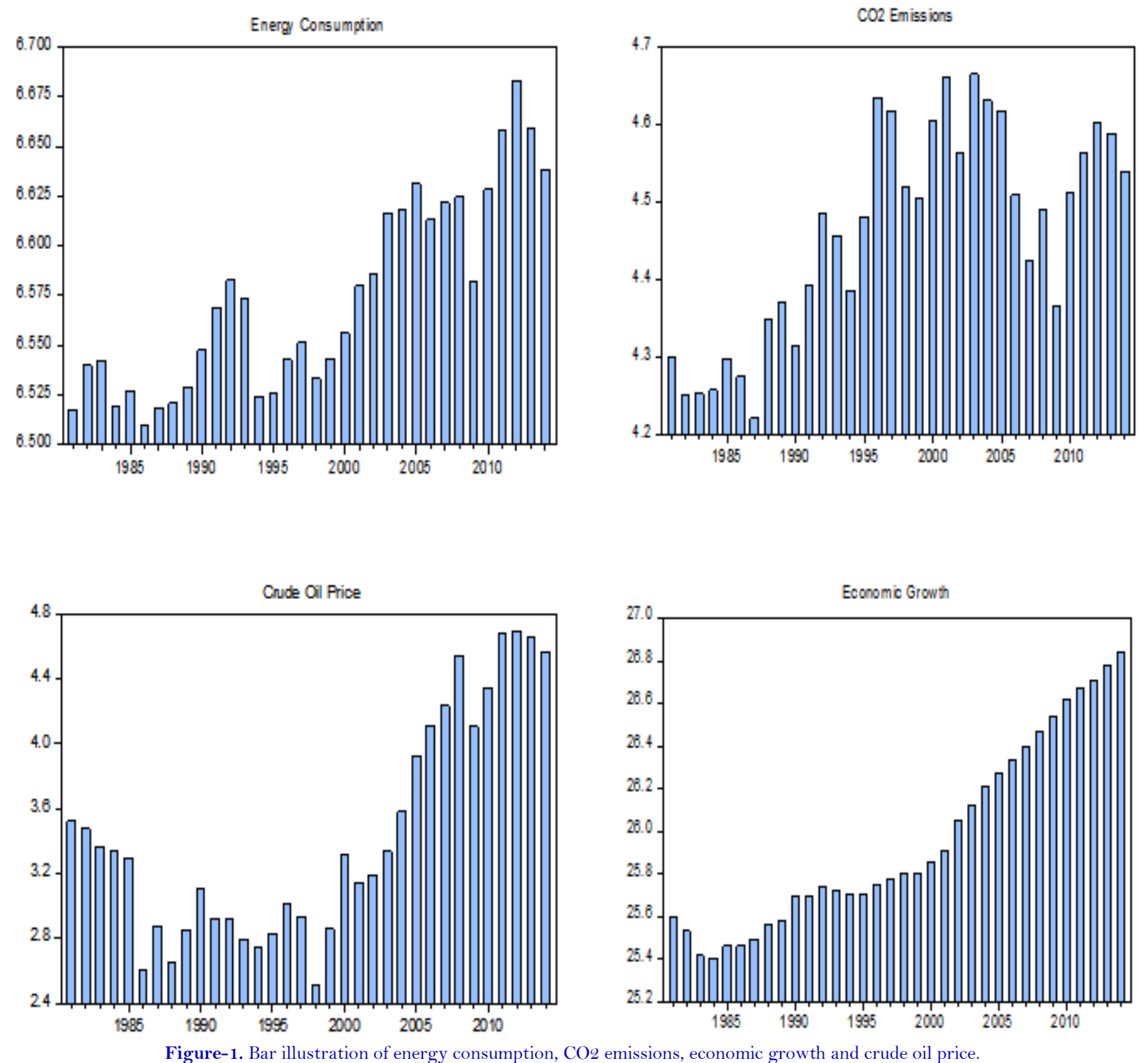

4.1. Descriptive Analysis

The descriptive analysis reported in Table 1 depicted that on a comparative analysis, the standard deviation values for all the variables are very far below their mean and the median values and that signifies the level of variability of the series. The outcome also revealed that $\mathrm{CO}_{2 \mathrm{t}}$ emissions was skewed negatively, while the rest of the variables were positively skewed. Energy consumption, economic growth and crude oil price have platykurtic distribution because their kurtosis values are less than 3 whereas $\mathrm{CO}_{2 t}$ emissions kurtosis value has mesokurtic distribution. The Jarque-Bera values implies that all the variables are normally distributed within the sample period of 1981 to 2014 because the probability values of these variables are not significant. 
Table-1. Descriptive Statistics.

\begin{tabular}{c|c|c|c|c}
\hline Description & $\operatorname{lnCO}_{\boldsymbol{t}}$ & $\operatorname{lnEC}_{\mathrm{t}}$ & $\operatorname{lnGDP}_{\mathbf{t}}$ & $\operatorname{lnOP}_{\mathrm{t}}$ \\
\hline Mean & 4.461314 & 6.573908 & 25.96180 & 3.442907 \\
\hline Median & 4.487282 & 6.562645 & 25.78684 & 3.307011 \\
\hline Maximum & 4.664571 & 6.682898 & 26.83758 & 4.695468 \\
\hline Minimum & 4.220243 & 6.510120 & 25.40412 & 2.507972 \\
\hline SD. & 0.137524 & 0.049092 & 0.444265 & 0.684896 \\
\hline Skewness & -0.219054 & 0.520918 & 0.606392 & 0.616705 \\
\hline Kurtosis & 1.752327 & 2.061604 & 2.015859 & 2.043494 \\
\hline Jarque-Bera & 2.477219 & 2.785182 & 3.455784 & 3.451288 \\
\hline Probability & 0.289787 & 0.248431 & 0.177659 & 0.178058 \\
\hline Observations & 34 & 34 & 34 & 34 \\
\hline
\end{tabular}

\subsection{Correlation Analysis}

Table 2 conveyed the outcome of correlation analysis. The outcome of the analysis shows that all the variables have positive correlation with $\mathrm{CO}_{2}$ emissions and this implies that increase in any of the energy consumption, economic growth and oil price will cause increase in the level of $\mathrm{CO}_{2}$ emissions and most importantly, the correlation coefficients for all the series are within 0.80 and this means the absence of multicollinearity problem among our explanatory series (Pordan, 2013).

Table-2. Correlation Analysis.

\begin{tabular}{c|c|c|c|c}
\hline Variables & $\operatorname{lnCO} \mathbf{C O}_{\mathbf{t}}$ & $\operatorname{lnEC}_{\mathrm{t}}$ & $\operatorname{lnEG}_{\mathbf{t}}$ & $\operatorname{lnOP}_{\mathbf{t}}$ \\
\hline $\ln _{\mathrm{CO}}$ & 1.000 & & & \\
\hline $\operatorname{lnEG}_{\mathrm{t}}$ & 0.629 & 1.000 & & \\
\hline $\ln \mathrm{EC}_{\mathrm{t}}$ & 0.586 & 0.922 & 1.000 & \\
\hline $\operatorname{lnOP}_{\mathrm{t}}$ & 0.287 & 0.840 & 0.867 & 1.000 \\
\hline
\end{tabular}

\subsection{Unit Root Test Results}

With regards to the estimation process mentioned earlier in the research methodology section, we utilized the $\mathrm{ADF}$ and PP unit root tests and the results are reported in Table 3. The outcomes of the two tests revealed that all the series are were not stationary at level values or they have unit root but became stationary after first differencing. Therefore, all the variables are said to be integrated of order 1 or I (1) and is efficient for cointegration analysis. Consequently, we continue to test for the presence of cointegration relationship using ARDL bound test.

Table-3. ADF and PP unit root test results

\begin{tabular}{|c|c|c|c|c|c|c|c|c|}
\hline \multirow[b]{3}{*}{ Variables } & \multicolumn{4}{|c|}{ At Level } & \multicolumn{4}{|c|}{ At First Difference } \\
\hline & \multicolumn{2}{|c|}{ ADF } & \multicolumn{2}{|c|}{$\mathbf{P P}$} & \multicolumn{2}{|c|}{ ADF } & \multicolumn{2}{|c|}{$\mathbf{P P}$} \\
\hline & Constant & $\begin{array}{l}\text { Constant } \\
\text { \& Trend }\end{array}$ & Constant & $\begin{array}{l}\text { Constant } \\
\text { \& Trend }\end{array}$ & Constant & $\begin{array}{l}\text { Constant } \\
\& \text { Trend }\end{array}$ & Constant & $\begin{array}{c}\text { Constant \& } \\
\text { Trend }\end{array}$ \\
\hline $\ln \mathrm{CO}_{\mathrm{t}}$ & $\begin{array}{l}-1.8098 \\
(0.3694)\end{array}$ & $\begin{array}{l}-2.3469 \\
(0.3988)\end{array}$ & $\begin{array}{l}-1.6008 \\
(0.4709)\end{array}$ & $\begin{array}{l}-2.3770 \\
(0.3839)\end{array}$ & $\begin{array}{c}-3.9567 \\
(0.0232)^{* * * *}\end{array}$ & $\begin{array}{c}-6.1958 \\
(0.0000)^{* * * * * *}\end{array}$ & $\begin{array}{c}-7.4191 \\
(0.0000)^{* * * *}\end{array}$ & $\begin{array}{c}-11.5330 \\
(0.0000)^{* * * *}\end{array}$ \\
\hline $\operatorname{lnEG}_{\mathrm{t}}$ & $\begin{array}{c}1.8921 \\
(0.9996)\end{array}$ & $\begin{array}{l}-1.7577 \\
(0.6957)\end{array}$ & $\begin{array}{c}1.9665 \\
(0.9998)\end{array}$ & $\begin{array}{l}-2.5580 \\
(0.3004)\end{array}$ & $\begin{array}{c}-4.0635 \\
(0.0037)^{* * * * *}\end{array}$ & $\begin{array}{c}-3.4932 \\
(0.0583)^{*}\end{array}$ & $\begin{array}{c}-3.6301 \\
(0.0106)^{* * *}\end{array}$ & $\begin{array}{c}-4.0238 \\
(0.0179)^{* * *}\end{array}$ \\
\hline $\operatorname{lnEC_{t}}$ & $\begin{array}{l}-1.1487 \\
(0.6843)\end{array}$ & $\begin{array}{l}-2.6712 \\
(0.2541)\end{array}$ & $\begin{array}{l}-0.9528 \\
(0.7582)\end{array}$ & $\begin{array}{l}-2.3953 \\
(0.3750)\end{array}$ & $\begin{array}{c}-5.2217 \\
(0.0002)^{* * * * *}\end{array}$ & $\begin{array}{c}-5.1588 \\
(0.0011)^{* * * *}\end{array}$ & $\begin{array}{c}-5.8895 \\
(0.0000)^{* * * * * *}\end{array}$ & $\begin{array}{c}-7.2377 \\
(0.0000)^{* * * * *}\end{array}$ \\
\hline $\ln \mathrm{OP}_{\mathrm{t}}$ & $\begin{array}{l}-0.3868 \\
(0.9002)\end{array}$ & $\begin{array}{l}-2.1638 \\
(0.4930)\end{array}$ & $\begin{array}{l}-0.2278 \\
(0.9251)\end{array}$ & $\begin{array}{l}-2.0866 \\
(0.5339)\end{array}$ & $\begin{array}{c}-4.4687 \\
(0.0013)^{* * * * *}\end{array}$ & $\begin{array}{c}-5.1316 \\
(0.0013)^{* * * * *}\end{array}$ & $\begin{array}{c}-6.1154 \\
(0.0000)^{* * * * *}\end{array}$ & $\begin{array}{c}-7.0813 \\
0.0000)^{* * * * *}\end{array}$ \\
\hline
\end{tabular}

\subsection{ARDL Bounds Test Result}

The long run and short run estimated elasticities coefficients as of the chosen Equations 2 and 3 of the ARDL model are presented in Table 4. At the beginning, in order to test for the presence of long run equilibrium relationship, we utilize the bond test on $\beta_{1}=\beta_{2}=\beta_{3}=\beta_{4}=0$ null hypothesis in order to validate the existence 
of the relationship from Equation 3. By looking at our calculated F-statistic value which is 4.5537 is strong enough to reject the null hypothesis $\beta_{1}=\beta_{2}=\beta_{3}=\beta_{4}=0$ and confirmed the existence of cointegration relationship in

Equation 3.

Table-4. ARDL bounds test result.

\begin{tabular}{c|c|c}
\hline ARDL bound test: & \multicolumn{2}{c}{ Restricted constant and no trend } \\
\hline Estimated Equation & \multicolumn{2}{c}{$\ln C \boldsymbol{O}_{2 t}=f\left(\ln E C_{t}, \ln E G_{t}, \ln \boldsymbol{O P}\right)$} \\
\hline Optimal lag length & $(1,3,3,2)$ \\
\hline F-statistic value & $4.5537^{* *}$ \\
\hline Significant level & Lower bounds values (0) & Upper bounds values (1) \\
\hline $10 \%$ & 2.37 & 3.2 \\
\hline $5 \%$ & 2.79 & 3.67 \\
\hline $1 \%$ & 3.65 & 4.66 \\
\hline
\end{tabular}

The long-run and the short-run outcome for the estimated models are given in Table 5. Starting with the longrun coefficients, the $\mathrm{EC}_{\mathrm{t}}$ has significant positive influence on $\mathrm{CO}_{2 \mathrm{t}}$ and its elasticity coefficient shows that increase in $\mathrm{EC}_{\mathrm{t}}$ by 1 percent is associated with 3.9782 percent rise in $\mathrm{CO}_{2 \mathrm{t}}$ in the country. This substantiates the facts that energy consumption by commercial and domestic sectors of the economy leads to environmental pollution via $\mathrm{CO}_{2}$ emissions. This finding followed the results of Shahbaz et al. (2013) for Malaysia, Sulaiman and Abdul-Rahim (2017) for Malaysia and Mahmooda et al. (2019) for Saudi Arabia.

$\mathrm{EG}_{\mathrm{t}}$ is also positive and significant at 5 percent level of significance and the elasticity value indicate that a percentage increase in $\mathrm{EG}_{\mathrm{t}}$ is associated with 0.5207 percent increase in $\mathrm{CO}_{2 \mathrm{t}}$ in the long-run period. And this is inconformity with the idea that increasing economic growth is connected with the growing sectoral energy consumption in the country. The results support the findings of researchers such as Onafowora and Owoye (2014) for Egypt, Ibrahiem (2015) for Egypt, Sulaiman and Abdul-Rahim (2017) for Malaysia, Manu and Sulaiman (2017) for Malaysia, Mahmooda et al. (2019) for Saudi Arabia, but contradict the findings of Mohammad Salahuddin and Gow (2014) for no relationship between economic growth and pollution.

But $\mathrm{OP}_{t}$ depicted a significant negative relationship with $\mathrm{CO}_{2 \mathrm{t}}$ at 1 percent level of significance and the elasticity parameter described that 1 percent rise in $\mathrm{OP}_{t}$ will bring about 0.4379 percent decrease in $\mathrm{CO}_{2 \mathrm{t}}$ in the long-run. The finding supports the assumption that revenue realized from crude oil exports are employed in maintaining the environmental quality and the finding corroborate the empirical outcomes of Saboori, Rasoulinezhad, and Sung (2017) for Japan and China.

The error correction term $\left(\mathrm{ECT}_{\mathrm{t}-1}\right)$ has satisfied all the econometric conditions of being negative, less than 1 and significant. Therefore, this shows the presence of short-run relationship and the speed of adjustment which is at 0.483 percent per year after disequilibrium and towards achieving equilibrium. The short-run $\mathrm{EC}_{\mathrm{t}}$ has significant positive impact on $\mathrm{CO}_{2 \mathrm{t}}$ and the elasticity coefficients indicate that 3.2201 percent rise in $\mathrm{CO}_{2 \mathrm{t}}$ is realized from 1 percent increase in energy consumption. Moreover, $\mathrm{EG}_{\mathrm{t}-1}$ and $\mathrm{EG}_{\mathrm{t}-2}$ revealed a significant negative relationship with $\mathrm{CO}_{2 \mathrm{t}}$ and precisely, percentage increase in $\mathrm{EG}_{\mathrm{t}-1}$ and $\mathrm{EG}_{\mathrm{t}-2}$ have negative effect on $\mathrm{CO}_{2 \mathrm{t}}$ in the short run period. The coefficient of $\mathrm{OP}_{\mathrm{t}}$ has negative and significant impact on $\mathrm{CO}_{2 \mathrm{t}}$ in the short-run. Specifically, 1 percent rise in the $\mathrm{OP}_{\mathrm{t}}$ will result in 0.1174 percent decrease in $\mathrm{CO}_{2 \mathrm{t}}$.

Table 6 reported the result from our reliability tests and the results shows smaller F-statistics and greater probability values which suggests the absence of econometric problems in our model and we are good to go for the next step in the estimation process. 
Table-5. Long-run and short-run models result.

\begin{tabular}{|c|c|c|}
\hline \multicolumn{3}{|c|}{ Dependent variable $=\ln \mathrm{CO}_{2 \mathrm{t}}$} \\
\hline & Coefficients & T-Statistics (P-values) \\
\hline \multicolumn{3}{|c|}{ Long-run coefficients } \\
\hline $\ln \mathrm{EC}_{\mathrm{t}}$ & 3.9782 & $1.7906(0.0902)^{*}$ \\
\hline $\ln \mathrm{EG}_{\mathrm{t}}$ & 0.5207 & $2.4494(0.0248)^{* *}$ \\
\hline $\ln \mathrm{OP}_{\mathrm{t}}$ & -0.4379 & $-4.6835(0.0002)^{* * * *}$ \\
\hline Constant & -33.6016 & $-2.9180(0.0092)^{* * *}$ \\
\hline \multicolumn{3}{|c|}{ Short-run coefficients } \\
\hline$\Delta \ln \mathrm{EC}_{\mathrm{t}}$ & 3.2201 & $4.1171(0.0006)^{* * * *}$ \\
\hline$\Delta \ln \mathrm{EC}_{\mathrm{t}-1}$ & -0.0116 & $-0.0158(0.9876)$ \\
\hline$\Delta \ln \mathrm{EC}_{\mathrm{t}-2}$ & -1.0256 & $-\mathrm{X} .5880(0.1297)$ \\
\hline$\Delta \ln \mathrm{EG}_{\mathrm{t}}$ & 0.0623 & $0.1911(0.8505)$ \\
\hline$\Delta \ln \mathrm{EG}_{\mathrm{t}-1}$ & -0.5274 & $-1.7735(0.0931)^{*}$ \\
\hline$\Delta \ln \mathrm{EG}_{\mathrm{t}-2}$ & -0.7854 & $-2.3809(0.0285)^{* * *}$ \\
\hline$\Delta \ln \mathrm{OP}_{\mathrm{t}}$ & -0.1174 & $-1.9594(0.0657)^{*}$ \\
\hline$\Delta \ln \mathrm{OP}_{\mathrm{t}-1}$ & 0.0670 & $1.4699(0.1589)$ \\
\hline Constent & -16.2480 & $-2.8829(0.0099)^{* * *}$ \\
\hline $\operatorname{ECM}(-1)$ & -0.4835 & $-5.2752(0.0001)^{* * *}$ \\
\hline
\end{tabular}

Table-6. Reliability tests.

\begin{tabular}{c|c|c}
\hline Test statistics & F Version & LM version \\
\hline A: Serial correlation & $1.8238[0.1946]$ & $3.0036[0.0831]$ \\
\hline B: Heteroscedasticity & $0.5530[0.8511]$ & $8.3507[0.7572]$ \\
\hline C: Normality & $2.4473[0.2941]$ & Not applicable \\
\hline Dote: Functional Form & $0.3642[0.5541]$ & $0.6035[0.5541]$ \\
\hline
\end{tabular}

A: Breusch-Godfrey Serial Correlation LM test.

B: Based on Breusch-Pagan-Godfrey.

C: Based on Jarque-Bera test.

D: Ramsey RESET test using squares of fitted values.

Passing all the reliability tests as shown in Table 6 does not implies that the model is steady and to achieve this purposing of obtaining stable and steady model, we have utilized the stability test with CUSUM and CUSUM of squares residual stability tests as suggested by Brown, Durbin, and Evans (1975) and the plots are consistent with the long-run and short-run through residuals and as far as the plots are inside the $5 \%$ critical bounds, then one can conclude that the regression parameters are stable and consistent. Figure 2 illustrates the stability test outcome.

(A)

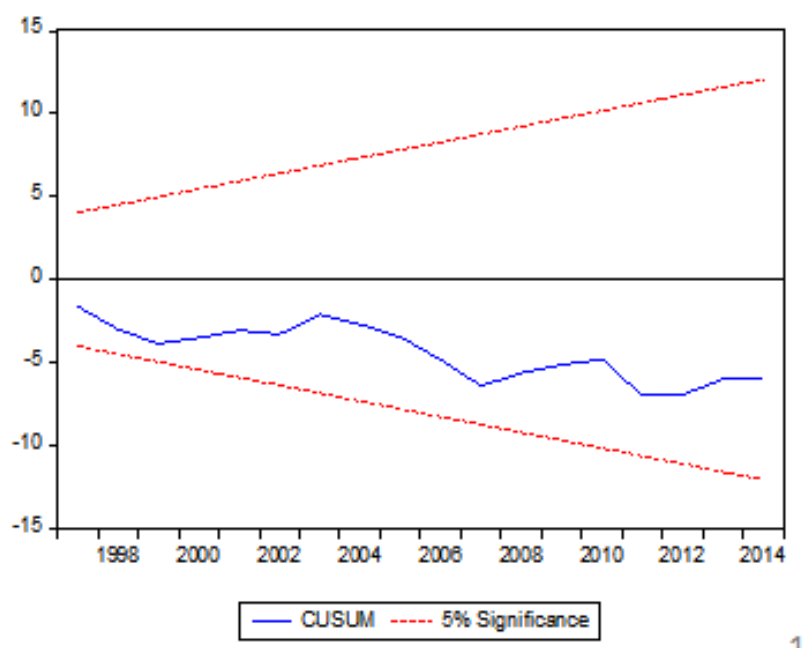

(B)

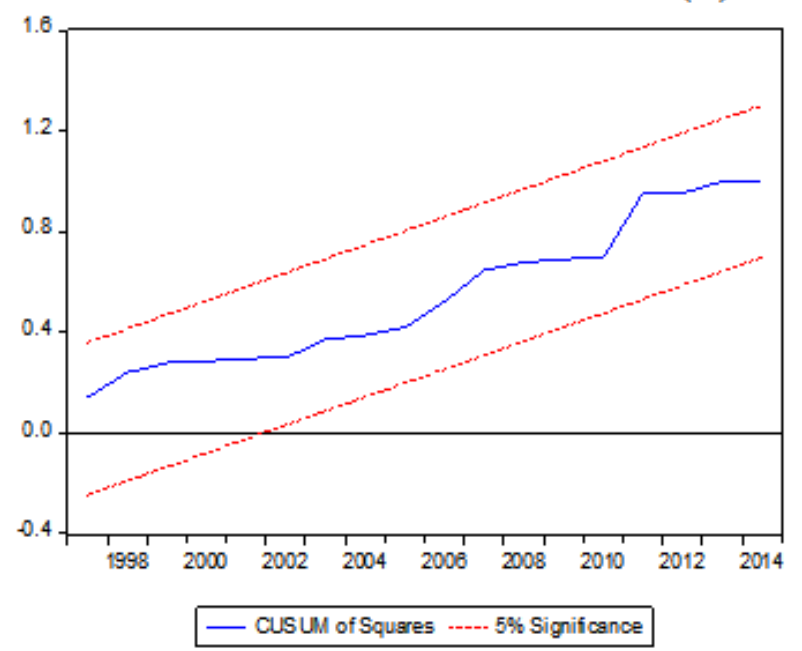

Figure-2. Stability test (A) Plot of CUSUM (B) Plot of CUSUM of Squares. 


\section{CONCLUSION}

In any economy around the globe, economic growth is the most required phenomena even though it is associated with some undesirable effects and the greatest among them is environmental pollution. We have examined the influenced of energy consumption, economic growth and crude oil price on carbon dioxide emissions in Nigeria over 1981-2014 periods and applied ARDL approach. The presence of long run and short run connections were tested in the carbon dioxide emissions model and the we are able to discovered that the growing rate of economic growth is associated with rising level of carbon dioxide emissions. This implies that growing demand for pollution related consumption in the country is connected with growing economic and development activities. We have also showed that energy consumption brings about higher level of carbon dioxide emissions and this is true because the greatest source of energy consumption for the country is coming from fossil fuel with very little from renewable energy. While crude oil price has negative influence on the level of carbon dioxide emissions and this implies that revenue realized through crude oil exports is spent on activities that improves the quality of the environmental in the country. Therefore, in summary, increasing levels of economic growth and energy consumption are accountable for the increasing level of carbon dioxide emissions in the country. Among our recommendations include, Nigeria government should emphasis more on the consumption of renewable energy in order to lessen the damaging impacts of economic activities and fossil fuels energy consumption on the quality of the country's environment.

Funding: This study received no specific financial support.

Competing Interests: The authors declare that they have no competing interests.

Acknowledgement: Both authors contributed equally to the conception and design of the study.

\section{REFERENCES}

Acaravci, A., \& Ozturk, I. (2010). On the relationship between energy consumption, $\mathrm{CO} 2$ emissions and economic growth in Europe. Energy, 35(12), 5412-5420. Available at: https://doi.org/10.1016/j.energy.2010.07.009.

Ahmad., M., Hengyi, H., Rahman, Z. U., Khan, Z. U., Khan, S., \& Khan, Z. (2018). Carbon emissions, energy use, gross domestic product and total population in China. Economics and Environment, 2(65), 32-44.

Ahmed, K., Shahbaz, M., Qasim, A., \& Long, W. (2015). The linkages between deforestation, energy and growth for environmental degradation in Pakistan. Ecological Indicators, 49, 95-103. Available at: https://doi.org/10.1016/j.ecolind.2014.09.040.

Alkhateeb, T. T. Y., Alkahtani, N. S., \& Mahmood, H. (2018). Green human resource management and pollution nexus in Saudi Arabia. International Journal of Energy Economics and Policy, 8(3), 33-36.

Alper, A., \& Oguz, O. (2016). The role of renewable energy consumption in economic growth: Evidence from asymmetric causality. Renewable and Sustainable Energy Reviews, 60(C), 953-959. Available at: https://doi.org/10.1016/j.rser.2016.01.123.

Amri, F. (2017). The relationship amongst energy consumption (renewable and non-renewable), and GDP in Algeria. Renewable and Sustainable Energy Reviews, 76, 62-71. Available at: https://doi.org/10.1016/j.rser.201 7.03.029.

Arouri, M. E. H., Youssef, A. B., M'henni, H., \& Rault, C. (2012). Energy consumption, economic growth and CO2 emissions in Middle East and North African countries. Energy Policy, 45, 342-349. Available at: https://doi.org/10.1016/j.energy.2019.03.126.

Balcilar, M., Ozdemir, Z. A., Ozdemi, H., \& Shahbaz, M. (2018). Carbon dioxide emissions, energy consumption and economic growth: The historical decomposition evidence from G-7 countries. 1-44.

Bloch, H., Rafiq, S., \& Salim, R. (2012). Coal consumption, CO2 emission and economic growth in China: Empirical evidence and policy responses. Energy Economics, 34(2), 518-528. Available at: https://doi.org/10.1016/j.eneco.2011.07.014. 
Brown, R. L., Durbin, J., \& Evans, J. M. (1975). Techniques for testing the constancy of regression relationships over time. Journal of the Royal Statistical Society: Series B (Methodological), 37(2), 149-163. Available at: https://doi.org/10.1111/j.2517-6161.1975.tb01532.x.

Dickey, D. A., \& Fuller, W. A. (1981). Likelihood ration statistics for autoregressive time series with a unit root. Econometrica, 49(4), 1057-1072.

Epule, T. E., Peng, C., \& Lepage, L. (2014). Environmental refugees in sub-Saharan Africa: A review of perspectives on the trends, causes, challenges and the way forward. Geojournal, 80(1), 79-92.

Fatiha, B., \& Karim, M. (2019). Key determinants of energy demand: Case of Morocco. International Journal of Economics and Finance, $11(5)$, 50-58. Available at: https://doi.org/10.5539/ijef.v 11 n5p50.

Hassan, S. (2018). Long run energy demand and its determinants: A panel cointegration analysis of the Association of Southeast Asian Nations-5. International Journal of Energy Economics and Policy, 8(4), 270-279.

Hassan., M., Tahir, M., Wajid, A., Mahmood, H., \& Farooq, A. (2017). Natural gas consumption and economic growth in Pakistan: Production function approach. Global Business Review, 19(2), 1-14.

Ibrahiem, D. M. (2015). Renewable electricity consumption, foreign direct investment and economic growth in Egypt: An ARDL approach. Procedia Economics and Finance, 30, 313-323. Available at: https://doi.org/10.1016/s22 12-567 1(15)01299-x.

Isik, C., Dogru, T., \& Turk, E. S. (2018). A nexus of linear and non-linear relationships between tourism demand, renewable energy consumption, and economic growth: Theory and evidence. International Journal of Tourism Research, 20(1), 3849. Available at: https://doi.org/10.1002/jtr.2151.

Khobai, H., \& Le Roux, P. (2017). The relationship between energy consumption, economic growth and carbon dioxide emissions: The case of South Africa. International Journal of Energy Economics and Policy, 7(3), 102-109.

Khoshnevis Yazdi, S., \& Shakouri, B. (2017). Renewable energy, nonrenewable energy consumption, and economic growth. Energy Sources, Part B: Economics, Planning, and Policy, 12(12), 1038-1045. Available at: https://doi.org/10.1080/15567249.2017.1316795.

Koçak, E., \& Sarkgüneşi, A. (2018). The impact of foreign direct investment on CO 2 emissions in Turkey: new evidence from cointegration and bootstrap causality analysis. Environmental Science and Pollution Research, 25(1), 790-804. Available at: https://doi.org/10.1007/s1 1356-017-0468-2.

Kouton, J., \& Amonle, S. (2019). The dynamic impact of renewable energy consumption on economic growth: The case of cote d'Ivoire. Journal of Economics and Sustainable Dvelopment, 10 (18), 167-174

Kraft, J., \& Kraft, A. (1978). On the relationship between energy and GNP. The Journal of Energy and Development, 3(2), 40 1-403.

Mahmood, H., Furqan, M., \& Bagais, O. A. (2019). Environmental accounting of financial development and foreign investment: Spatial analyses of East Asia. Sustainability, 11(13), 1-16.

Mahmooda, H., Alkhateeba, T. T. Y., Al-Qahtani, M. M. Z., Allam, Z., Ahmad, N., \& Furqan, M. (2019). Energy consumption, economic growth and pollution in Saudi Arabia. Management Science Letters, 1O(5), 979-984.

Maji, I. K. (2015). The link between trade openness and deforestation for environmental quality in Nigeria. Geo Journal, 82(1), $131-138$

Manu, S. B., \& Sulaiman, C. (2017). Environmental Kuznets curve and the relationship between energy consumption, Economic growth and $\mathrm{CO} 2$ emissions in Malaysia. Journal of Economics and Sustainable Development, 8(16), 142-148.

Mirza, F. M., \& Kanwal, A. (2017). Energy consumption, carbon emissions and economic growth in Pakistan: Dynamic causality analysis. Renewable and Sustainable Energy Reviews, 72, 1233-1240. Available at: https://doi.org/10.1016/j.rser.2016.10.081.

Musa, K. S., Maijama'a, R., Shaibu, H. U., \& Muhammad, A. (2019). Crude oil price and exchange rate on economic growth: ARDL approach. Open Access Library Journal, 6(e5930), 1-16.

Okwanya, I., \& Abah, P. O. (2018). Impact of energy consumption on poverty reduction in Africa. CBN Journal of Applied Statistics, 9(1), 105-139. 
Onafowora, O., \& Owoye, O. (2014). Bounds testing approach to analysis of the environmental kuznet curve hypothesis. International Journal of Energy Economics and Policy, 44(C), 47-62. Available at: https://doi.org/10.1016/j.eneco.2014.03.025.

OPEC. (2020). Organization of oil exporting countries crude oil prices 1960-2020. Retrieved from: https://www.statista.com/statistics/262858/change-in-opec-crude-oil-prices-since/1960/.

Pesaran, M. H., Shin, Y., \& Smith, R. J. (2001). Bounds testing approaches to the analysis of level relationships. Journal of Applied Econometrics, 16(3), 289-326. Available at: https://doi.org/10.1002/jae.616.

Phillips, P. C., \& Perron, P. (1988). Testing for a unit root in time series regression. Biometrics, 75(2), 335-346.

Pordan, I. (2013). The effects of whether on stock returns: A comparison between emerging and developed markets (pp. 1-54). Germany: Anchor Academic Publishing.

Saboori, B., Rasoulinezhad, E., \& Sung, J. (2017). The nexus of oil consumption, CO 2 emissions and economic growth in China, Japan and South Korea. Environmental Science and Pollution Research, 24(8), 7436-7455. Available at: https://doi.org/10.1007/s1 1356-017-8428-4.

Salahuddin, M., Alam, K., Ozturk, I., \& Sohag, K. (2017). The effects of electricity consumption, economic growth financial development and foreign direct investment on $\mathrm{CO} 2$ emissions in Kuwait. Renewable and Sustainable Energy Reviews, 81(P2), 2002-2010. Available at: https://doi.org/10.1016/j.rser.2017.06.009.

Salahuddin, M., \& Gow, J. (2014). Economic growth, energy consumption and $\mathrm{CO} 2$ emissions in Gulf Cooperation Council countries. Energy, 73, 44-58. Available at: https://doi.org/10.1016/j.energy.2014.05.054.

Sarkodie, S. A., \& Strezov, V. (2019). Effect of foreign direct investments, economic development and energy consumption on greenhouse gas emissions in developing countries. Science of the Total Environment, 646, 862-871. Available at: https://doi.org/10.1016/j.scitoenv.2018.07.365.

Shahbaz, M., Solarin, S. A., Mahmood, H., \& Arouri, M. (2013). Does financial development reduce CO2 emissions in Malaysian economy? A time series analysis. Economic Modelling, 35, 145-152. Available at: https://doi.org/10.1016/j.econmod.2013.06.037.

Ssali, M. W., Du, J., Mensah, I. A., \& Hongo, D. O. (2019). Investigating the nexus among environmental pollution, economic growth, energy use, and foreign direct investment in 6 selected sub-Saharan African countries. Environmental Science and Pollution Research, 26(11), 11245-1 1260.

Sulaiman, C., \& Abdul-Rahim, A. (2017). The relationship between CO 2 emission, energy consumption and economic growth in Malaysia: A three-way linkage approach. Environmental Science and Pollution Research, 24(32), 25204-25220. Available at: https://doi.org/10.1007/s11356-017-0092-1.

WDI. (2020). World Bank's world development indicators. Retrieved from: https://data.worldbank.org/indicator. 